\title{
Foreign Words and Phrases in Newspaper Film Reviews
}

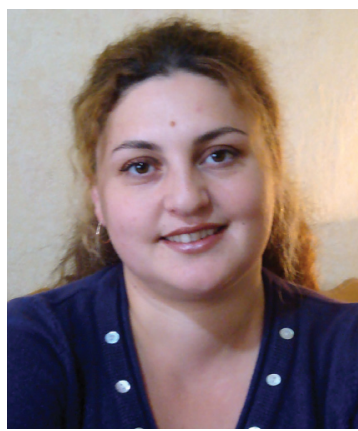

Irina Vardanyan
Foreign words and phrases shouldn't become a bête noire, but, ceteris paribus, English sentences should be in English...

Jack Lynch

Throughout its history, English has been shaped and enriched by words and phrases of French, Scandinavian, Italian, Latin, Greek and German origin. When cultures come into contact with one another, borrowing takes place primarily in the realm of lexical terms (Anderson 1973). As A. I. Smirnitsky points out, a foreign word is a shapeless piece of material, which gains its shape only by means and in the system of the new language (Smirnitski 1954). Many words of foreign origin have been in English for so long that they have been freely integrated and can no longer be distinguished from English words and may not trigger a sense of "foreignisms". However, there are cases, when the word is not assimilated and retains its foreign language spelling, pronunciation as well as connotation. Such cases are perceived as "organic inclusions" (Smirnitski 1954).

Depending on the degree of adaptation of an originally "alien" word to its new linguistic surroundings, linguists distinguish between foreign words and loanwords. However, the borderline between them is blurred and a concise classification is not always an easy task.

In this article the word foreign is used for those borrowed words which have not been accepted by the English as "part and parcel" of the language, or in other words, had not been naturalized yet (Lindgren 1943:240).

The use of foreign words and word combinations in film reviews has direct connection with the peculiarity of the newspaper style. Along with informing the reader about the film, they gain the readers' attention and make an impression on him. Being aware of their expressive power, the reviewer uses a number of foreign words and phrases in the text. These units can be perceived as elegant and educated, and they are likely to show up in the writing of individuals who seek to give a special elevated touch to their work.

It is worth mentioning, that this means of expression is more productive when it does not arouse extra difficulties in understanding the whole text. For this purpose, the reporter should take into account both the educational and social status of his reader. $\mathrm{He}$ should be aware of the background knowledge of his reader to successfully establish contact with the latter.

The use of foreign words and word combinations in film reviews perform both expressive and informative functions. It is possible to show how the relationship between these two functions changes depending on the role of foreign words and phrases in the text of film reviews. A comparison of film reviews published at the same period of time 
on the same film but in newspapers of different social orientation will help to show how the choice between a foreign word and its functional English equivalent depends on the readers' social and educational status. The usage of foreign words and word combinations is considered to be marked, as they reveal not only the reader's, but also the reviewer's social status.

However, this phenomenon is not always socially marked. The admixture of foreign words is one of the distinguishing peculiarities of newspaper style. It should be noted that some foreign words as vanilla, visa, blitz, etc., are so commonly or long used in newspapers in general and film reviews in particular that they have become totally familiar to the reader and there is no need to print them in italics. On the other hand, a number of loanwords, such as cliché, coup de theatre, etc., keep their original spelling, Foreign words and word combinations of this type are also widely used both in quality and mass newspapers.

Below are some examples of foreignisms, the use of which is not limited to the social and educational status: they are found in both quality and mass newspapers.

\section{Film bible Variety says: 'The indisputable raison d'etre for About Schmidt is to showcase Jack Nicholson giving a master class in the art of screen acting.}

The Daily Mail, January 22, 2005

The sequence was, above all, a remarkable tour de force of editing, but its emotional effect depended on the identification the viewer brought earlier in the film to the sympathetic and vulnerable figure that Leigh presented.

The Guardian, October 5, 2004

The performance is extraordinary tour de force.

Her company Gravity \& Levity has been launched with an ambitious programme of live performance and film that tours until June 25.

The Daily Express, June 1, 2005

The coincidence of sound and meaning of such words with homonymous English words improves understanding. In the last example, the reviewer successfully matches the French phrase tour de force with the English word tour, thus adding to the better understanding of the whole text. As seen from the examples in both quality and mass newspapers the foreign word is introduced without any explanation. The absence of any comment is explained by the fact that such units do not have an important role in the understanding of the whole text. Their function is to draw the reader's attention to the text of some particular review.

To foreignisms also belong a number of terms of foreign origin relating to arts: painting, music, theater, etc., such as premiere, denouement, leitmotiv, etc. However some of them have a restricted use, mainly restricted to the educational level.

E.g. 
More recently there was, the knockabout 70 s heist romp written by TV veterans Clement and La Frenais that attracted large numbers of Americans to a story involving Princess Margaret and a denouement at Paddington station (and which, together with the now-cancelled US version of Life on Mars may have helped nudge the door open for Peace's altogether more hellish vision of the same era).

Sunday Telegraph, June 29, 2008

Aycborn leitmotiv abound: male obtuseness provoking female desperation.

The Financial Times, December 20, 2009

The frequency of foreign word usage varies between newspapers aimed at different audiences. It is common knowledge that compared with mass newspapers, the quality ones frequently contain a higher proportion of foreign words and phrases.

Reporters like to use foreign words when they mention foreign films in an attempt to arouse their readers' interest or to express the connotations of the words more properly.

E.g.

Inside, designer Paul Wills lays on an impressive coup de theatre for the torture chambers in the Ministry of Love.

The Daily Mail, March 5, 2010

Columbia Studios gave him carte blanche, and Clouzot went ahead with Serge Regianni and Romy Schneider starring and three full camera crews. The Observer, November 8, 2009

The most original thing about Peter Sollett's film about teenage angst is its title, taken from Rachel Cohn and David Levithan's novel of the same name.

Evening Standard January 1, 2009

As it is seen from the examples adduced above, foreign words are introduced to the text differently, depending on the author's intention and the readers' background knowledge. In the given examples foreign words are used without any explanation and comment since they are known to the reader. The reviewer gives explanations to the foreign words in case the reader lacks some particular background information to understand House word. The purpose is to avoid misunderstanding of the whole context.

Sometimes the writer, who likes to avail himself of a foreign word, either to make a genuine point or to show that he has the gift of tongues, uses literal translation instead of the actual word not to keep his less favored readers in the dark. 
On 4 October 1976, the strip was launched. Woody, the pen-and-ink protagonist, was angst-ridden: flawed, fearful, insecure, inadequate, pessimistic, urban, single, lustful, rejected by women.

The Guardian, October 19, 2009

It should be noted that the English equivalents of the German word angst cannot be considered pure translation as they have different shades of meaning and the former has additional emotional-expressive-evaluative connotations due to its foreign origin. Thus, despite the fact, that the word angst is freely used by the English, it still retains some of its sociolinguistic connotations peculiar to German.

Foreign words and word combinations are getting to be freely interspersed through English. Many of them retain their original pronunciation in order to add some extra coloring to the whole text. The reviewer takes particular care to linguistically liven up his text, to describe the scenes more authentically by adding local coloring to his speech. The foreign words introduced in the text without any explanation, help the author to achieve some stylistic effect. In this case, there is no need to understand the meaning of the word as only the foreign word form is relevant here. When reading a review readers feel they are closer to the reality of the film characters and their language.

In the following example in order to vividly transmit the local coloring of the film the reviewer uses the French word directrice which is well known to the broad public:

One laughs as Madame Dubonnet, directrice of a Nice finishing school, is reunited with the English millionaire.

Sunday Telegraph, June 22, 2004

The journalist usually acts in his own interest to provide optimal stylistic effectiveness for the reader. He aims at evoking interest, understanding or reacting to the feelings in the audience. On the other hand, foreignisms are conspicuous when embedded in English sentences, and thereby catch the readers' attention (Pfitzner 1978:122). Foreignisms are also used for emphasis, to achieve intensification of expression in particular.

It's done with relish and syle, much helped by Robin's set: the plage and the terrasse of the Cafe Pataplon.

Standard, June2, 2004

Here the reviewer prefers the French word plage to its neutral English equivalent beach, and uses terrasse as he intends to transfer to his reader the local atmosphere of a fashonable and luxurious rest house.

However, when using a foreign word the reviewer always takes into consideration his readers' background knowledge, social and educational status. Otherwise he can lead the reader to misunderstanding, as the reader can fail to understand the whole passage 
because of a foreign word. Reporters writing for quality papers are relatively free in introducing foreign elements in the text only when they are sure that the reader will not only understand the meaning of the foreign word, but also highly appreciate the stylistic effect brought in by the foreign word.

It should be noted that if there exists a more or less adequate English equivalent for the foreign word, the reviewer of mass newspapers tends to use the native equivalent, whereas in quality papers the foreign equivalents are preferred. This can be well illustrated in the following examples, where the same film is reviewed in newspapers of different social orientation.

The period is the 19th century. With a happy sense of fun, the King of Navarre and his three cronies are seen as pompous highbrows in graduate's gowns...

Daily Telegraph, December 10, 2006

We are in the turn-of-the century France.

Daily Express, November 27, 2006

Mr. Kyle sets the action in the period of the early belle epoque.

The Guardian, November10, 2006

It is clearly seen from the examples that only in the last passage printed in the Guardian, the author describes the period of settled and comfortable life preceding the war of 1914-1918 by a French phrase belle époque. This contextually and syntactically important expression is not commented upon, as it is well known to the reader of the Guardian. There is no doubt that compared with such natural expressions as the period is the $19^{\text {th }}$ century or the turn-of-the century France the French phrase implies more emotional-expressive connotations due to its foreign origin. It can be said that in the given examples the foreign words perform both informative and expressive functions.

Thus, it can be concluded that foreign elements imply additional local colouring to the text of the review. Generally spoken, the adoption of foreign words is motivated by potential profit, be it need or prestige. Moreover, there is a wide spread opinion that the use of foreign words belong to a more "educated" register. Indeed, by virtue of its being foreign, a word attains greater saliency and acquires greater expressive power.

\section{References:}

1. Anderson, M.H. (2002) Engelsk I Dansk. // Sprogholding I. Denmark. Kopenhavn: Kopenhavn Universitet.

2. Lindgren, H.C. (1942) The Relationship Between Foreign Language Courses of Study and Foreign Words in Newspaper English. Stanford: Stanford University Press. 
3. Pfitser, J. (1978) Der Anglicismus in Deuchen. Vol. 51. Stuttgart: J.B. Metzlersche Verlagsbuch handlung.

4. Smirnitsky, A.I. (1954) Obyektivnost sushchestvovaniya yazika. // Materialy k kursam yazikoznaniya. V.A. Zveginceva (Ed). M: MGU.

\section{Ounup puntipfi ns punuluuumugnıpjnıfifitipn lhGinqpu|ununıpjufi untpuinnıu}

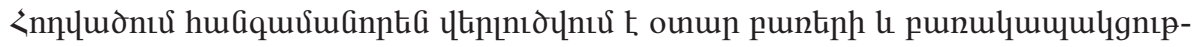

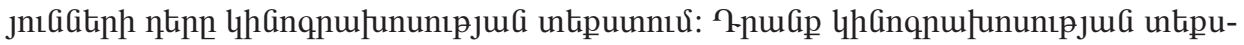

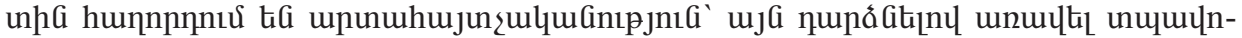

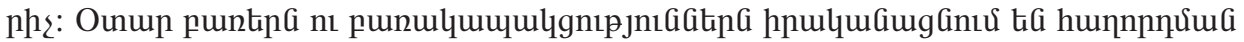

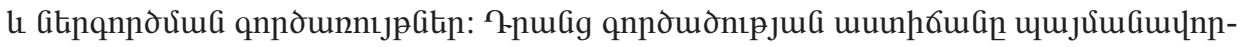

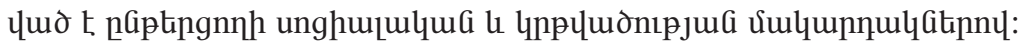

